\title{
THE SHIFTING TRENDS IN TRAVELLING AFTER THE COVID-19 PANDEMIC
}

\author{
Dewi Ayu Kusumaningrum ${ }^{1}$, Suci Sandi Wachyuni ${ }^{*}$ \\ ${ }^{1}$ Sahid Polytechnic, Indonesia; ${ }^{2 *}$ Sahid Polytechnic, Indonesia and Postgraduate Tourism Studies Programme, Universitas \\ Gajah Mada, Indonesia. \\ Email: ${ }^{1}$ dewiayu1908@gmail.com; ${ }^{2 *}$ suci.sandi.wachyuni@mail.ugm.ac.id
}

Article History: Received on $15^{\text {th }}$ August 2020, Revised on $22^{\text {nd }}$ September 2020, Published on $1^{\text {st }}$ October 2020

\begin{abstract}
Purpose of the study: This study is to understand the shifting trends in traveling after the Covid-19 pandemic. This research was also conducted to determine tourist behavior by identifying the typology of tourists and tourists' traveling motivation after the Covid-19 pandemic.

Methodology: This research is a quantitative descriptive study. The data were collected from an online questionnaire (Google Form) contains statements that are rated on a 5-point Likert scale ranging from strongly disagree to strongly agree. Data were analyzed using descriptive statistics, i.e. distribution of frequency, percentage, and average value. The research time was during March-April 2020. The sample was 100 Indonesian respondents, and all data were valid to be analyzed in the study.

Main Findings: Millenial tourists were dominated in this study. The results show that tourists' typology tends to the explorer type, and the second position refers to the drifter type. Meanwhile, the motivation was dominated by physical or physiological motivation and followed by interpersonal motivation. Therefore, natural destinations are the primary choice in the respondent's travel plans.
\end{abstract}

Applications of this study: This result may be used as a reference for destination managers in formulating management strategies and destination development after the pandemic period. The tourism industry may also use the findings of this study to plan tourism activities and develop policies in the new normal era.

Novelty / Originality of this study: This research is original, and this is the first study that identifying the shifting trends in traveling after Covid-19 pandemic.

Keywords: Covid-19 Pandemic, Coronavirus, Tourists' Typology, Motivation to Travel, Millenials.

\section{INTRODUCTION}

Covid-19 pandemic has changed all aspects of human life, including tourism. Policies and travel restrictions implemented in several countries have influenced the perception of tourist tourism during a pandemic or after the pandemic has ended. Based on research with respondents in Indonesia, the majority of respondents in this study have an interest in traveling after the pandemic and show a negative response to anxiety, have planned when and where they will travel, with a period $(0-6)$ months after the Covid-19 pandemic ends and nature tourism as a favorite choice. This result shows the view that basically travels is a human need today (Wachyuni \& Kusumaningrum, 2020).

Other studies have revealed that safety, security, and health risks that are considered negatively can affect tourists' perceptions of tourist destinations so that they are more likely to look for tourist destinations that are equipped with the quantity and quality of infrastructure that follows the required health protocols (Wen, Kozak, Yang, \& Liu, 2020). The tourism industry must be able to immediately change its short-term business strategy with consideration of financial risks while still prioritizing the health of tourists. It is estimated that the tourism industry will bounce back after a year of the pandemic (Assaf \& Scuderi, 2020). Although there are risks that may be faced, there are tourists who like challenges with high resistance to the various risks that may be faced during the trip. Previous research has shown that tourists consider the potential high risk on a tourist trip to be an interesting part of a tour (Yang \& Nair, 2014).

This research is supported by a global study that suggests $80 \%$ of travelers are willing to pay more for safer accommodation, and $76 \%$ of respondents stated that their preferred travel destinations are countries that offer more travel experiences with restricted physical contact (TheJakartaGlobe, 2020). Currently, many amusement parks around the world have reopened during the Covid-19 pandemic. For example, in Orlando, Florida, Walt Disney World reopened 11 July 2020 with reduced capacity provisions and other safety measures to protect tourists, such as the obligation to use masks, except when eating or swimming and hand sanitizing facilities are available throughout the park. Based on interviews with tourists, visitors feel that this is the entertainment they need, a pleasant experience, relieving stress, being able to play with satisfaction due to reduced capacity, so the waiting time for each attraction is swift. Even though the visitors who come are only around $17 \%$ of capacity, the Walt Disney World managers are optimistic that it will be better (Usatoday.com, 2020). 
The enthusiasm for tourism is also seen in the European region. On the first big holiday of the summer weekend in July 2020, there was an increase in the influx of foreign tourists at all border crossings into the country despite the ongoing Covid-19 pandemic. With the conditions required at each crossing, the restrictions do not discourage their travel intentions. For example, on the Greek-Bulgarian border, thousands of tourists wait for hours in lines of up to 15 kilometers at the Kulata-Promachonas border checkpoint (Euronews.com, 2020). These conditions prove that tourists' perceptions of tourism during a pandemic or after a pandemic are more flexible but still pay attention to health protocols.

Modern human tourists are willing to accept changes in travel, very capable of adapting to new environments, looking forward to different things even though they are not fully prepared for the new environment (Cohen, 1972). Apart from the restraints of quarantine provisions for over five months in several countries. Most of the studies reviewed reported negative psychological effects of quarantine, including symptoms of stress, confusion, anger, frustration, boredom, financial loss (Brooks, Smith, \& Webster, 2020). Tourism experience is felt necessary to overcome all the negative effects of the ongoing pandemic. The extent to which tourists want the tourist experience on a particular tour depends on the tourists' individual tastes and preferences.

Motivation is an attribute that affects all activities undertaken. This leads to persuasive feelings that always provide positivism to react and get something to meet their needs (Gopalan, Abu Bakar, Zulkifli, Alwi, \& Che Mat, 2017). Consumer motivation is the main factor that needs to be studied in determining a suitable business strategy involving consumers and producers (Šimková \& Holzner, 2014). In this study, identified the types of tourists and their motivation to travel after the Covid-19 pandemic. This study aims to determine the motivation of tourists related to the classification of types of tourists.

There is quite a lot of research on travel motivation. Research on the push and pull theory of motivation in Saudi tourists shows that the most important push and pull factors are cultural and religious values (Bogari, Crowther, \& Marr, 2003). Factor-analyzing research in Figler's Travel Motivation Survey of five orthogonal factors, namely anomie/search for authenticity, culture/education, escape / regression, desire to wander/ explore the unknown, and jet-set / prestige search (Figler, Weinstein, Sollers III, \& Devan, 1992). Other research on rural tourism in Korea identified four tourist segments based on tourism motivation: family togetherness seekers, passive tourists, want-it-all seekers, and learning and excitement seekers (Park \& Yoon, 2009).

However, there has not been much research related to tourism motivation in the pandemic era. There is research on the impact of Covid-19 on the traveling motivation of Indonesian travelers to travel abroad, which focuses on discussing the cancellation or rescheduling of trips abroad (Rachmawati \& Shishido, 2020). Therefore, this research is expected to be a reference for destination managers in formulating management strategies and destination development after the pandemic period and can predict tourism trends after the pandemic period.

Tourist motivation affects tourism demand or the number of tourist arrivals to tourist destinations, so further research on tourism motivation is needed (Rickly, 2019). The Covid-19 pandemic has created a global tourism crisis; all parties are working together to accelerate the transformation of tourism adapted to current conditions. The tourism industry can use the information on the research results related to motivation and the types of tourists who will travel after the pandemic in planning tourism activities and developing policies to help attract more tourists who have been stopped from their tourism activities.

\section{LITERATURE REVIEW}

\section{Tourist Classification}

Tourist classification is often the subject of research by tourism researchers. Research on tourist classification aims to create tourist groups or destinations that have similar characteristics. It is hoped that it can help related to the problem of tourism demand and supply. It is important in the tourism decision-making process and policy formulation (Coccossis \& Constantoglou, 2006). Different types of tourists will affect tourism planning variations, seeking tourist information from external sources, destinations, duration of tours, and travel processes before making travel-related decisions (Grzywacz \& Zeglen, 2016). In the era of connectivity, online social contact has become a new habit for tourists and has a significant influence on behavior and experience (Buhalis \& Sinarta, 2019). Furthermore, (Fan, Buhalis, \& Lin, 2019) states that tourist typology needs to be identified based on online and face-to-face social contact to formulating effective marketing strategies for various segments.

Humans are generally more flexible regarding their environment, can change according to environmental conditions wherever they are. Tourism makes humans interested in the ordinary. When contact with new things makes them attractive to them, supported by increased awareness of the outside world seems to lead to an increased readiness to leave one's habitat and wander around temporarily or even emigrate to a habitat other. Despite being a novelty in the travel experience, humans are not fully prepared. It will still be tied to its original culture and previous habits, so there will still be adjustments to 
tourists' wishes. Cohen (1972) categorizes tourists into four different types based on individual preferences for novelty or familiarity with tourist destinations:

1. Organized mass tourists. The type of tourist who buys a tour package from a trusted travel agent only follows the travel agent's flow as planned by the travel agent. Familiarity level with a high but minimal level of novelty.

2. Independent mass tourist. The type of tourist who buys a package tour but the tour is not fully planned, the tourist has some control over his travel time and plans and is not tied to a group. However, all major arrangements are still made through travel agencies. The itinerary is not much different from the travel agent's plan. The familiarity level is still dominant but has a greater experience level of novelty.

3. Explorer. These types of tourist arranges his own trips, different from travel plans in general, but still pay attention to comfortable and safe accommodation, transportation and other tourist facilities. Trying to blend with a new environment at the tourist destination but retain some of the basic routines and comforts of the original way of life. These tourists are concerned about the risks involved if they become involved without paying attention to their basic needs.

4. Drifter. This type of tourist is very different from other tourists who want a unique tour, visit a place that is not a favorite tourist destination, try to blend in with a new environment, live in the way of the people in the places they visit. They do not have a fixed schedule and clear travel destination. The level of novelty is very high, but the level of familiarity is absent.

\section{Travel Motivation}

Motivation comes from the word "motive" which causes someone to take action in a certain way or something that stimulates desire (Utama \& Susanto, 2016). Motivation is fundamental in studying tourists because motivation is the "trigger" of the trip, even though tourists themselves are often not aware of the motivation, but they are essential. Motivation is the driving force for tourists to decide on tourism options based on individual preferences, previous experiences, and information obtained (Pitana \& Gayatri, 2005). Tourism motivation is a force that encourages tourists to visit a tourist destination (Dagustani, Kartini, Oesman, \& Kaltum, 2018).

In Maslow's theory of motivation, the motivation for travel and tourism activities is to improve health and well-being. Travel and tourism activities can become physiological needs, security needs, self-esteem, and self-actualization needs (Utama \& Susanto, 2016). Dann's motivation theory, there are push factors and pull factors that motivate tourists to travel. Driving factors or intrinsic factors include the desire to rest, recreation, experience adventure, and escape from a contemporary lifestyle. Conversely, pull factors, or eccentric factors associated with destination facilities, such as services, prices, and tourist facilities (Yousaf, Amin, \& Santos, 2018).

The motivation of a person to do travel and tourism activities is divided into four groups (Pitana \& Gayatri, 2005), namely as follows:

1. Physical or physiological motivation is physical or physiological motivation, for relaxation, health, comfort, participating in sports activities, recreation. Relaxation is physical and mental rest so that the body becomes more relaxed, comfortable (Dwisaputra \& Achnes, 2017). This motivation purely comes from within a person's body who needs to feel relaxed, relaxes tense muscles from working or studying hard, refreshes a stressed mind, so it is feared that it will affect physical and psychological health if not done. This description is similar to several research results that examined the motivation of tourists to travel: relaxation motivation, enriching and learning experiences, participation in recreational activities, increasing personal values, and social experiences (Vuuren \& Slabbert, 2011). Tourism activities undertaken to positively influence life satisfaction, even for a short trip (two days or less), can make body relaxation and recovery from work stress (Chen, Shahvali, \& Petrick, 2014).

2. Cultural motivation is the desire to know the culture, customs, traditions, and other regional arts, including those of interest to cultural heritage objects. The rules that apply to a community, so that members of the community can adjust their actions to the behavior they make, which makes tourists have the experience of following the rules and increasing the values of life (Dwisaputra \& Achnes, 2017).

3. Social motivation or interpersonal motivation is the desire to socialize, meet other people to talk about new things, visit friends and family, meet partners, do things that are considered to be proud of themselves with what is achieved or an honor. Another point is the need to learn about the country and travel for social interaction, interacting with local people who can offer tourists learning experiences (Vuuren \& Slabbert, 2011).

4. Fantasy motivation is a wish that exists in the mind of a person who wants to get away from the monotonous routine of daily life and is associated with psychological gratification. It can be called status and prestige motivation, which is related to a person's desire to be appreciated, respected, and admired to fulfill personal ambition (Dwisaputra \& Achnes, 
2017). For example, in anime tourism, anime tourists have a higher fantasy motivation with a greater level of involvement, which is an important point in the development of this type of tourism (Kirillova, Peng, \& Chen, 2019).

\section{METHODOLOGY}

This research is a quantitative descriptive study that is considered general for the discussion of tourism. It follows current problems or updates, studies changes in phenomena, and aims to present and describe the characteristics of the subject under study (Rebuya, Lasarte, Amador, \& Roca, 2020). This study describes the types of tourists and their motivation to travel after the current global problem, namely the Covid-19 pandemic. The Covid-19 pandemic changes all aspects of life, including tourism, which is related to change the mindset of tourists in dealing with the Covid-19 pandemic. This study aims to determine the motivation of tourists related to the classification of tourist types.

A questionnaire-based survey method was used. The survey method is one of the many tools used by researchers in the tourism sector. Data collection was carried out by distributing online questionnaires (Google Form) through the WhatsApp broadcast messages. An online survey was conducted responses and was beneficial for capturing from various areas of Indonesia. A survey with a questionnaire is suitable for gathering information about individual characteristics, perceptions, attitudes, and behavior. The survey stages are designing a questionnaire, choosing a survey strategy, in this case, an online survey and selecting respondents (Clifford, Cope, Gillespie, \& French, 2016).

The first stage is designing a structured questionnaire containing statements related to the type of tourists and tourism motivation after the pandemic, which is rated on a 5-point Likert scale ranging from strongly disagree to strongly agree. The questionnaire is divided into three parts: the profile of respondents, the tourist classification, and travel motivation. Respondent profiles include gender, age, educational and occupational background, and several closed questions related to tourism interest after the pandemic. The second part regarding the classification of tourists, which consists of several statements, refers to Cohen's theory. The third part is about motivation described in several statements, which refers to Pitana and Gayatri's theory. The results will then be analyzed in simple quantitative terms, i.e. the distribution of frequency, percentage, and average value.

The research time was during March-April 2020 when the whole world, especially Indonesia, was experiencing the Covid-19 pandemic. The second stage of selecting the chosen survey strategy is the online survey method that allows reaching various respondents in various regions, especially at this time. There are restrictions on physical contact that are applied in all regions in Indonesia. This strategy used is in line with the increasing use of technology in various studies that make it easier for respondents to answer questions and researchers in data collection and analysis. The advantages of online surveys for respondents include flexibility, convenience in answering questions, and being fast (Evans \& Mathur, 2005).

The third stage is the selection of respondents. The sample comprises people who will be given a questionnaire representing the population (Clifford et al., 2016). The sample was obtained by probability by a simple random sampling of 100 Indonesian respondents, and all data are valid to be analyzed in the study. Sampling uses some form of random selection, which requires setting up a process or procedure that ensures that different members of the target population have an equal probability of being selected is due to the large tourist population in Indonesia (Jager, Putnick, \& Bornstein, 2017).

\section{RESULTS}

\section{Profile and Characteristics of Survey Respondents}

Based on online survey results, the majority of respondents are women at $60 \%$. Most respondents were in the $31-40$ years range of $41 \%$, followed by the $21-30$ years age range of $35 \%$. The latest education for bachelor degree is $40 \%$, postgraduate is $30 \%$, and high school equivalent is $30 \%$. The respondents' occupations were mostly private employees at $43 \%$, followed by students at $27 \%$. Profile data and respondent characteristics can be seen in Table 1.

Table 1: Profile and Characteristics of Survey Respondents

\begin{tabular}{lll}
\hline Demography & Option & Percentage (\%) \\
\hline Gender & Male & 40 \\
\cline { 2 - 3 } & Female & 60 \\
\cline { 2 - 3 } & $17-20$ years old & 10 \\
\cline { 2 - 3 } & $21-30$ years old & 35 \\
\cline { 2 - 3 } & $31-40$ years old & 41 \\
\cline { 2 - 3 } & $>40$ years old & 14 \\
\hline Education Background & Senior High School & 30 \\
\cline { 2 - 3 } & Bachelor Degree & 40 \\
\cline { 2 - 3 } & Post Graduate & 30 \\
\hline
\end{tabular}




\begin{tabular}{lll}
\hline Occupation & Student & 27 \\
\cline { 2 - 3 } Private Employee & 43 \\
\hline Government Employee & 3 \\
\cline { 2 - 3 } & Entrepreneur & 6 \\
\cline { 2 - 3 } & Lecturer & 9 \\
\cline { 2 - 3 } & Others & 12 \\
\hline
\end{tabular}

The profile of respondents who filled out the questionnaire was dominated by generation Y, who in 2020 were $31-40$ years old. According to Bencsik, Juhász, \& Horváth-Csikós (2016), generation Y is people born in 1980-1995, or the year 2020 aged 25-40 years. Other sources mention that generation $\mathrm{Y}$ is also called the millennial generation born between 1980 and 2001 (Berkup, 2014) or 1980 to 2000 (Stafford \& Griffis, 2008).

\section{Intention to Travel}

Based on the survey results, most of the respondents, as many as $82 \%$, stated that they had planned to travel after the Pandemic, $16 \%$ answered maybe, and only $2 \%$ answered no. The choice of destinations is more on domestic destinations. The types of tourism that are the most preferred are nature tourism (67\%), followed by culinary tourism (17\%), and cultural tourism (9\%). The length of the planned trip is dominated by a short period of 1-4 days. Survey data related to intention to travel can be seen in Table 2 .

Table 2: Intention to Travel Responses

\begin{tabular}{lll}
\hline Questions Item & Options & Answer \% \\
\hline I have planned a trip after Pandemic & Yes & 82 \\
\cline { 2 - 3 } & Maybe & 16 \\
\cline { 2 - 3 } & No & 2 \\
\hline Destination preferences & Domestic & 50 \\
\cline { 2 - 3 } & Overseas & 4 \\
\cline { 2 - 3 } & Domestic and Overseas & 46 \\
\hline Type of destinations & Nature Tourism & 67 \\
\cline { 2 - 3 } & Culinary Tourism & 17 \\
\cline { 2 - 3 } & Culture Tourism & 9 \\
\cline { 2 - 3 } & Religious Tourism & 5 \\
\cline { 2 - 3 } & Others & 2 \\
\hline Length of the trip that has been planned & $1-4$ days & 55 \\
\cline { 2 - 3 } & & $5-7$ days \\
\cline { 2 - 3 } & $>7$ days & 10 \\
\hline
\end{tabular}

\section{Tourists' Typology Identification}

The statement on the questionnaire uses the basis of Cohen's (1972) tourist typology theory. Based on the research data in Table 3, it is known that the highest average of respondents' answers leads to the explorer classification, namely 3.96 or as much as $28.77 \%$ of the total respondents. On average, respondents agreed that after this Pandemic, they wanted to plan and create their itinerary and go on walks where they could interact with the environment and local communities. Furthermore, the respondents' answers were dominated by the drifter tourist typology, which was similar to the explorer type where they chose destinations they had never visited and travelled in small numbers. Meanwhile, in the third position, the respondents' answers refer to the typology of individual mass tourists, and the last one is the typology of organized mass tourists. The result of tourist typology identification can be seen in Table 3.

Table 3: Typology of Tourists

\begin{tabular}{|c|c|}
\hline Typology of Tourists & $\begin{array}{ll}\text { Mean Value } & \begin{array}{l}\% \text { of Total } \\
\text { Respondents }\end{array} \\
\end{array}$ \\
\hline \multicolumn{2}{|l|}{ Drifter } \\
\hline $\begin{array}{l}\text { After the Pandemic is over, I want to travel where I have never been } \\
\text { before }\end{array}$ & 4.22 \\
\hline I prefer travelling alone or with just a few friends & 3.58 \\
\hline Average Mean Value & 28,37 \\
\hline
\end{tabular}




\begin{tabular}{|c|c|c|}
\hline $\begin{array}{l}\text { After the Pandemic is over, I want to plan and create my travel } \\
\text { itinerary } \\
\text { After the Pandemic is over, I want to travel and interact with the } \\
\text { environment and local people }\end{array}$ & 3.83 & \\
\hline Average Mean Value & 3.96 & 28,77 \\
\hline \multicolumn{3}{|l|}{ Individual mass tourist } \\
\hline After the Pandemic is over, I would like to travel using a travel agent & 2.75 & \\
\hline $\begin{array}{l}\text { After the Pandemic is over, I would like to visit a well-known tourist } \\
\text { destination }\end{array}$ & 3.56 & \\
\hline Average Mean Value & 3.16 & 22,95 \\
\hline \multicolumn{3}{|l|}{ Organized mass tourist } \\
\hline $\begin{array}{l}\text { After the Pandemic is over, I want all my trips to be organized by } \\
\text { travel agents and tour guides }\end{array}$ & 2.63 & \\
\hline After the Pandemic is over, I only want to visit popular destinations & 2.83 & \\
\hline Average Mean Value & 2.73 & 19,87 \\
\hline
\end{tabular}

\section{Travelling Motivation After Pandemic}

As for analyzing travel motivation based on their travel activities (Pitana \& Gayatri, 2005). Based on the results of the study, the highest average answer was 4.34 where the majority of respondents agreed-strongly agreed that their travelling activity was to relax their body and mind or was called physical or physiological motivation. In the second position, respondents have interpersonal motivation, i.e. travelling to meet relatives, friends, or new friends. In the third position, respondents want to travel to be able to find new things that are different from the usual or what is called fantasy motivation, and for the last one is cultural motivation, which is the motivation of tourists to know the local culture. The survey data of traveling motivation after pandemic can be seen in Table 4.

Table 4: Traveling motivation after Pandemic

\begin{tabular}{ll}
\hline Travelling motivation & Mean Value \\
\hline Physical on physiological motivation & \\
\hline $\begin{array}{l}\text { I will travel after the Covid-19 Pandemic because I want to relax my body } \\
\text { and mind }\end{array}$ & 4.34 \\
\hline Cultural motivation & \\
\hline $\begin{array}{l}\text { I will travel after the Covid-19 Pandemic because I want to know the local } 3.80 \\
\text { culture }\end{array}$ \\
\hline interpersonal motivation \\
\hline $\begin{array}{l}\text { I will travel after the Covid-19 Pandemic to meet new relatives, friends or } 4.12 \\
\text { friends }\end{array}$ \\
\hline Social motivation \\
$\begin{array}{l}\text { I will travel after the Covid-19 Pandemic to fulfil my need for self- } 3.06 \\
\text { recognition }\end{array}$ \\
\hline Fantasy motivation \\
\hline $\begin{array}{l}\text { I will travel after the Covid-19 Pandemic to find new things that are } \\
\text { different from usual }\end{array}$
\end{tabular}

\section{DISCUSSION}

\section{Tourist's Profile, Characteristics, and Travel Intention}

The characteristics of tourists in this study were dominated by tourists aged 31-40 years or called the millennial generation (Bencsik et al., 2016; Berkup, 2014; Stafford \& Griffis, 2008). This millennial generation has "unique" characteristics, the technology used in every activity, including travelling (Wachyuni \& Wiweka, 2020). They like everything that is practical and innovative (Kusumaningrum \& Wachyuni, 2020) and has great potential for the future tourism industry (Damanik, Wachyuni, Wiweka, \& Setiawan, 2019). Female respondents dominate in this study. According to Omar, Abooali, Mohamad, \& Mohamed (2015), gender influences tourist travel patterns, travel preferences and experiences, travel motivation, participation in recreational activities, tourism concepts and leisure motivation as well as travel decision-making processes.

As for the educational background of the respondents, it is dominated by bachelor degree graduates. According to (Keumala, Samad, Samad, \& Rachmawaty, 2019), Educational background has impacted the respondents' motivation. It can be said that 
with higher education, the higher the tourism motivation. The majority of jobs are as private employees. Meanwhile, the higher income will affect the desire to buy new things (Djeri, Jovanovic, Armenski, \& Dragin, 2014), in this case travelling to find new experiences.

This phenomenon evidenced by the majority of respondents' answers who stated that they had planned to take a tour after the Pandemic ended. Natural tourism destinations are the primary choice in the respondents' travel plans. According to (Wachyuni \& Kusumaningrum, 2020), health issues are part of the situation in the process of determining destinations. In Indonesia, natural tourist destinations are the first type of destination to open in the new normal adaptation because according to the Minister of Tourism and Creative Economy Wishnutama Kusubandio the risk of transmission is smaller than tourist destinations in the city centre (Tolok, 2020).

The results showed that domestic tourism became the choice of tourists after the Pandemic. Domestic travel is considered to have a lower risk due to short distances and travel times. This phenomenon positively affects international tourist visits around the world. The UNWTO (2020) has reported that there is a reduction of international tourist arrivals during the first quarter of 2020 as $22 \%$. Tourist arrivals fell $57 \%$ after lockdowns in many countries, national borders, and travel restrictions. Likewise in Indonesia, BPS, the Central Statistics Agency in Indonesia noted that the number of foreign tourist arrivals in April 2020 experienced a sharp decline, by $87.44 \%$ compared to the same month last year. The number of foreign tourists in April 2020 amounted to 160,000 people compared to the same period last year, which reached 1.27 million visits due to the Covid-19 Pandemic (Pertiwi, 2020).

Tourism has indeed become one of the most affected sectors worldwide. However, there are optimistic hopes because tourists still have a strong desire for travel. Wachyuni \& Kusumaningrum (2020) in their research, stated that the majority of respondents had planned a tour immediately 0-6 months after the Covid-19 Pandemic ended. Assaf \& Scuderi (2020) predict that the tourism industry will bounce back after a year of the Pandemic. As for some countries, also in Indonesia, domestic tourism activities in June 2020 began to be carried out by adapting to strict health protocols while keeping in view the development of the situation.

\section{Typology and Tourist Motivation during the Covid-19 Pandemic}

The analysis of tourist typology and motivation reinforces the profile and characteristics of tourists. Referring to the tourist classification theory, according to Cohen (1972), the results show that the typology of tourists tends to the explorer type, and the second position refers to the drifter type. The explorer type chooses to organize their trips, mingling with the new surroundings of the tourist destination while maintaining some basic routines and the comfort of their original way of life. Meanwhile, the drifter type wants a unique tour, visiting a place that is not a favourite tourist destination and mingling with a new environment. Meanwhile, the type of individual mass tourist and an organized mass tourist is in the last position.

After the Pandemic, tourists travelling in the post-Covid-19 era did not want to participate in mass tourism and instead preferred travel with an emphasis on experience. The phenomenon of the Covid-19 Pandemic shifts the trend of mass tourism which is characterized by the use of travel agent to become private tourism. This phenomenon has become a projection trend for tourism demand, such as the growth of free and independent travel, luxury and health travel, and health tourism. Nevertheless, the travel movement has also become more selective; in particular, tourists can take fewer trips but spend longer at their chosen destination (Wen et al., 2020).

When consumers become aware of a certain level of risk, their behaviour changes, from delaying purchases to using strategies designed to reduce the level of risk to a tolerable one. The higher the perceived risk, the more information tourists seek and the more rational the decision-making process will be (Grzywacz \& Zeglen, 2016).

The characteristics of respondents, who are the majority of the millennial generation, also influence the way they travel. Destination image will significantly affect their travel satisfaction (Li \& Ali, 2017). Planning their trips, limiting their travel with smaller groups, and choosing domestic natural tourist destinations are considered to be minimal risks after the Covid-19 Pandemic. The destination's safe image will give them the satisfaction of travelling.

The choice of natural tourist destinations is also related to travel motivation. Motivation is a series of biological and spiritual needs (Crompton \& McKay, 1997). Therefore, motivation is a major factor in the decision-making process (Yolal, Rus, Cosma, \& Gursoy, 2015). The results showed that tourist motivation was dominated by physical or physiological motivation. Boredom during self-quarantine during the Pandemic encourages respondents to travel with the aim of relaxation to rest physically and mentally so that the body becomes more relaxed and comfortable (Dwisaputra \& Achnes, 2017).

Natural tourism destinations are considered to be able to accommodate the respondent's need for relaxation. This result is corresponding with some research about the motivation of tourists visiting natural tourist destinations. Such as research conducted by Saayman, Slabbert, \& Van Der Merwe (2009) which mentions five motivational factors for travel in marine destinations in South Africa, including escape and relaxations, destination attractiveness, socialization, personal attachments, 
site attributes, and trip features. Other research states that the motivation of tourists to visit the beach is body-related motivations and mind-related motivations. Mind-related motivations including culture and nature and escapism-related motivations (Prebensen, Skallerud, \& Chen, 2010).

Interpersonal motivation is the next respondents' choice. According to Pitana \& Gayatri (2005), Interpersonal motivation is the desire to socialize, visit friends and family, and interact with new friends. This motivation appears because restrictions on social activities during the Pandemic do not allow meeting family or friends, so respondents hope to do so on trips in postpandemic.

Furthermore, fantasy motivation is the third respondents' choice. According to Utama (2012), fantasy motivation is the desire of tourists to break away from the monotonous routine of daily life and is related to psychological satisfaction. Monotonous routines with heavy social restrictions for everyone, so that respondents want a trip to get psychological satisfaction and release boredom.

Meanwhile, cultural motivation is in the last position of the respondents' choice. This motivation conforms to the research of Wachyuni \& Kusumaningrum (2020) that cultural tourism is not the primary destination for travel during the post-pandemic period. However, respondents prefer nature tourism and culinary tourism. This case comes up because respondents prefer to relax, release boredom during the Pandemic, and get new experiences to fulfil their travel satisfaction.

\section{CONCLUSIONS AND RECOMMENDATIONS}

This research provides theoretical implications that the Covid-19 Pandemic has shifted the trend of mass tourism into private tourism. This case is evidenced by the results of research, which states that tourist typology tends to lead to explorers and drifters. The Covid-19 Pandemic has changed travel habits to become more independent. Planning the own trip in small amounts is becoming a new trend. Conventional travel agent services are starting to be abandoned, especially with millennial characteristics that are practical and innovative. Technology is the main tool for travel starting from searching for information on the travel stages from pre, during and post-trip. Also, this study provides updated information related to tourist motivation after the Covid-19 Pandemic.

Besides the theoretical implications, this research also provides practical implications that destination managers need to make adjustments to the characteristics, typology and motivation of tourists. For example, developing destinations in terms of providing tourist attractions that emphasize new unique and memorable experiences, involving natural and local community contexts such as volunteerism, and other attractions that cannot be found in destinations in general.

This research also provides input for travel entrepreneurs and destination managers to adjust to technology. The use of technology is the main tool in travelling, starting from determining the transportation used, accommodation, and finding location information using the internet. Furthermore, travel entrepreneurs and destination managers need to shift their promotional activities to social media.

Further research recommendations to analyze tourist perceptions about travel during a pandemic with a qualitative study. Other research that can be carried out further is to identify what natural tourism activities are the destination choices, for example climbing mountains which are mostly done during the Pandemic in Indonesia. Other recommendations can also be identified on the types of tourism options and the enthusiasm of tourists on the e-tourism platform during a pandemic.

\section{LIMITATIONS}

The limitation of this research is only used quantitative descriptive studies; the research results will be more comprehensive if equipped with qualitative data, such as in-depth interviews with respondents. In-depth interviews are expected to be able to dig up more information related to changes in tourism trends after the Covid-19 Pandemic.

\section{REFERENCES}

1. Assaf, A., \& Scuderi, R. (2020). COVID-19 and the recovery of the tourism industry. Tourism Economic, 26(5), 731-733. https://doi.org/10.1177/1354816620933712

2. Bencsik, A., Juhász, T., \& Horváth-Csikós, G. (2016). Y and Z Generations at Workplaces. Journal of Competitiveness, 6(3), 90-106. https://doi.org/10.7441/joc.2016.03.06 https://doi.org/10.7441/joc.2016.03.06

3. Berkup, S. B. (2014). Working With Generations X And Y In Generation Z Period: Management Of Different Generations In Business Life. Mediterranean Journal of Social Sciences, 5(19). https://doi.org/10.5901/mjss.2014.v5n19p218

4. Buhalis, D., \& Sinarta, Y. (2019). Real-Time Co-Creation and Nowness Service: Lessons from Tourism and Hospitality. Journal of Travel \& Tourism Marketing, 36(5), 563-582.

5. Bogari, N., Crowther, G., \& Marr, N. (2003). Motivation for Domestic Tourism: A Case Study of the Kingdom of Saudi Arabia. Tourism Analysis, 8(2-4), 137-141. https://doi.org/10.3727/108354203774076625 
6. Brooks, S., Smith, L., \& Webster, R. (2020). The psychological impact of quarantine and how to reduce it: rapid review of the evidence. The Lancet, 395(10227), 912-920. https://doi.org/10.1016/S0140-6736(20)30460-8

7. Chen, C., Shahvali, M., Petrick, J. (2014). Tourism Experiences As a Stress Reliever. Journal of Travel Research, 55 (2), 150-160. https://doi.org/ 10.1177/0047287514546223

8. Clifford, N., Cope, M., Gillespie, T., \& French, S. (2016). Key Methods in Geography (Third Edition). Glasgow: Sage Publication.

9. Coccossis, H., \& Constantoglou, M. (2006). The use of typologies in tourism planning: problems and conflicts. Volos: Econstor. 46th Congress of the European Regional Science Association (ERSA) Enlargement, Southern Europe and the Mediterranean. Volos: econstor.

10. Cohen, E. (1972). Toward a Sociology of International Tourism. Political Economics, 39(1), 164-182. Retrieved from http://www.jstor.org/stable/40970087

11. Crompton, J. \& McKay, S. . (1997). Motives of Visitors attending Festival Events. Annals of Tourism Research, 24(2), 425-439. https://doi.org/10.1016/S0160-7383(97)80010-2

12. Dagustani, D., Kartini, D., Oesman, Y., \& Kaltum, U. (2018). Destination Image of Tourist: Effect of Travel Motivation and Memorable Tourism Experience. Etikonomi Volume, 17(2), 307-318. https://doi.org/10.15408/etk.v17i2.7211

13. Damanik, D., Wachyuni, S. S., Wiweka, K., \& Setiawan, A. (2019). The Influence of Social Media on the Domestic Tourist's Travel Motivation Case Study: Kota Tua Jakarta, Indonesia. Current Journal of Applied Science and Technology, 36(6), 1-14. https://doi.org/10.9734/cjast/2019/v36i630263

14. Djeri, L., Jovanovic, T., Armenski, T., \& Dragin, A. (2014). How income influences the choice of tourism destination? Acta Oeconomica, 64(2), 219-237. https://doi.org/10.1556/aoecon.64.2014.2.5

15. Dwisaputra, M., \& Achnes, S. (2017). Motivasi Pengunjung ke Kota Wisata Bukittinggi Sumatera Barat. Jurnal Online Mahasiswa Fakultas Ilmu Sosial Dan Ilmu Politik Universitas Riau OM FISIP, 4(2), 1-13.

16. Euronews.com. (2020). Tourists flock to European holiday destinations amid ongoing pandemic.

17. Evans, J. R., \& Mathur, A. (2005). The Value of Online Surveys. Internet Research, 15(2), 195-219. https://doi.org/10.1108/10662240510590360

18. Fan, D. X. F., Buhalis, D., \& Lin, B. (2019). A tourist typology of online and face-to-face social contact: Destination immersion and tourism encapsulation/decapsulation. Annals of Tourism Research, 78(102757). https://doi.org/10.1016/j.annals.2019.102757

19. Figler, M. H., Weinstein, A. R., Sollers III, J. J., \& Devan, B. D. (1992). Pleasure travel (tourist) motivation: A factor analytic approach. Bulletin of the Psychonomic Society, 30, 113-116. https://doi.org/10.3758/BF03330412

20. Gopalan, V., Abu Bakar, J., Zulkifli, A., Alwi, A., \& Che Mat, R. (2017). A Review of the Motivation Theories in Learning. The 2nd International Conference on Applied Science and Technology 2017 (ICAST'17) AIP Conference Proceedings 1891, 020043. https://doi.org/10.1063/1.5005376

21. Grzywacz, R., \& Zeglen, P. (2016). Typology of tourists and their satisfaction level. Scientific Review of Physical Culture, 6(1), 5-16.

22. Jager, J., Putnick, D. L., \& Bornstein, M. H. (2017). More than Just Convenient: The Scientific Merits of Homogeneous Convenience Samples. Monogr Soc Res Child Dev., 82(2), 13-30. https://doi.org/10.1111/mono.12296

23. Keumala, M., Samad, I., Samad, N. M., \& Rachmawaty, N. (2019). The Influence of Socio Cultural and Educational Background on EFL Learners' Motivation. Indonesian TESOL Journal, 1(1), 67-77. https://doi.org/10.24256/itj.v1i1.556

24. Kirillova, K., Peng, C., \& Chen, H. (2019). Anime consumer motivation for anime tourism and how to harness it. Journal of Travel \& Tourism Marketing, 36(2). https://doi.org/10.1080/10548408.2018.1527274

25. Kusumaningrum, D. A., \& Wachyuni, S. S. (2020). Promo Cashback GoPay Terhadap Minat Beli Bubble Drink (Studi Kasus: Yu Cha Indonesia, Pluit). Journal of Tourism and Economic, 3(1), 23-30.

26. Li, J., \& Ali, F. (2017). Age matters: how demographics influence visitor perception and attitude at the destination $\begin{array}{llllll}\text { level. Int. J. Innovation } & \text { Learning, } & \text { 21(2), }\end{array}$ https://doi.org/10.1504/IJIL.2017.10002131

27. Omar, S. I., Abooali, G., Mohamad, D., \& Mohamed, B. (2015). A study of gender differences: international tourists behaviour and the perception of Penang's attributes. The 2015 International Conference on Hospitality, Leisure, Sports, and Tourism (ICHLST 2015), 59-73. Bangkok.

28. Park, D. B., \& Yoon, Y. (2009). Segmentation by motivation in rural tourism: A Korean case study. Tourism Management, 30, 99-108. https://doi.org/10.1016/j.tourman.2008.03.011

29. Pertiwi, N. L. (2020). Jumlah wisman hanya 160000 pada April 2020 Menurun Tajam Akibat Pandemi. Retrieved August 18, 2020, from travel.kompas.com website: https://travel.kompas.com/read/2020/06/03/104711227/jumlahwisman-hanya-160000-pada-april-2020-menurun-tajam-akibat-pandemi 
30. Pitana, I. G., \& Gayatri, P. G. (2005). Sosiologi Pariwisata. Yogyakarta: Andi Offset.

31. Prebensen, N., Skallerud, K., \& Chen, J. . (2010). Tourist Motivation With Sun and Sand Destinations: Satisfaction and The WOM-effect. Journal of Travel and Tourism Marketing, 27(8), 858-873. https://doi.org/10.1080/10548408.2010.527253

32. Rachmawati, \& Shishido. (2020). Travelers' motivations to travel abroad during covid 19 outbreak. International Journal of Applied Sciences in Tourism and Events, 4(1), 1-11. https://doi.org/10.31940/ijaste.v4i1.1772

33. Rebuya, N., Lasarte, E., Amador, M. M., \& Roca, G. R. (2020). Assessing Religious Tourism Motivational Factors and Experiences of Visitors to Selected Religious Sites in Camarines Sur, Philippines. Scientific Research, 7. https://doi.org/10.4236/oalib.1106404

34. Rickly, J. (2019). The effects of covid-19 on the tourism industry will linger long after lockdowns are eased. Retrieved May 19, 2020, from https://blog.degruyter.com/the-effects-of-covid-19-on-the-tourism-industry-willlinger-long-after-lockdowns-are-eased/

35. Saayman, M., Slabbert, E., \& Van Der Merwe, P. (2009). Travel Motivations: a Tale of Two Marine Destination in South Africa. South African Journal For Research in Sport, Physical Education and Recreation, 31(1), 81-94. https://doi.org/10.4314/sajrs.v31i1.43794

36. Šimková, E., \& Holzner, J. (2014). Motivation of Tourism Participants. Procedia. Social and Behavioral Sciences, 159, 660-664. https://doi.org/10.1016/j.sbspro.2014.12.455

37. Stafford, D. E., \& Griffis, H. S. (2008). A Review of Millennial Generation Characteristics and Military Workforce Implications. In A Review of Millennial Generation Characteristics and Military Workforce Implications. Arlington: CNA Corporation.

38. The Jakarta Globe. (2020). Tourists from Five Countries Willing to Visit Indonesia Once Borders Reopen.

39. Tolok, A. D. (2020). Wisata Alam Jadi Andalan Indonesia di Tengah Pandemi. Retrieved August 17, 2020, from website: https://kabar24.bisnis.com/read/20200722/15/1269863/wisata-alam-jadi-andalan-indonesia-di-tengahpandem

40. Usatoday.com. (2020). Opening day at Disney World: Small crowds, short lines, social distancing and COVID-19 merch.

41. Utama, I. G. (2012). Motivation and Satisfaction of Senior Tourists for Traveling Overseas. Proceedings of the 13th IAMB Conference Fall 2012, 1-10. Bali: Conference: International Conference on Academy and Business.

42. Utama, I. G., \& Susanto, P. C. (2016). Destination development model for foreign senior tourists. Jbhost, 2(1), 1-16. https://doi.org/10.22334/jbhost.v2i1.35

43. Vuuren, C., \& Slabbert, E. (2011). Travel Motivations and Behaviour of Tourists To A South African. Book of Proceedings Vol. I - International Conference on Tourism \& Management Studies - ALGARVE 2011, 295-304. Algarve.

44. Wachyuni, S. S., \& Kusumaningrum, D. A. (2020). The Effect of Covid-19 Pandemic: How Are The Future Tourist Behavior? Journal of Education, Society and Behavioural Science, 33(4), 67-76. https://doi.org/10.9734/jesbs/2020/v33i430219

45. Wachyuni, S. S., \& Wiweka, K. (2020). Kepuasan Wisatawan dalam Penggunaan E-Commerce Agoda dalam Pemesanan Hotel. Journal of Tourism Destination and Attraction, 8(1). Retrieved from http://journal.univpancasila.ac.id/index.php/jtda/article/view/1366/958

46. Wen, J., Kozak, M., Yang, S., \& Liu, F. (2020). COVID-19: potential effects on Chinese citizens' lifestyle and travel. Tourism Review. https://doi.org/10.1108/TR-03-2020-0110

47. Yang, E. C., \& Nair, V. (2014). Tourism at Risk: A Review of Risk and Perceived Risk in Tourism. Journal of Innovation in Hospitality and Tourism APJIHT, 3(2), 239-259. https://doi.org/10.7603/s40930-014-0013-z

48. Yolal, M., Rus, R. ., Cosma, S., \& Gursoy, D. (2015). A Pilot Study on Spectators' Motivation and Their SocioEconomic Perception of a Film Festival. Journal of Convention \& Event Tourism, 16(3), 253-271. https://doi.org/10.1080/15470148.2015.1043610

49. Yousaf, A., Amin, I, Santos, J. (2018). Tourist's Motivations to Travel: A Theoretical Perspective on The Existing Literature. Tourism and Hospitality Management, 24 (1), 197-211. https://doi.org/10.20867/thm.24.1.8 